\title{
PRIMARY CARE QUALITY FROM PROFESSIONALS' PERSPECTIVE: HEALTH OF CHILDREN AND ADOLESCENTS WITH HIV ${ }^{1}$
}

\author{
Graziela Piovesan², Cristiane Cardoso de Paula, Luis Felipe Dias Lopes", Stela Maris de Mello Padoin ${ }^{5}$, \\ Raquel Einloft Kleinubing ${ }^{6}$, Clarissa Bohrer da Silva ${ }^{7}$
}

\begin{abstract}
${ }^{1}$ Research funded by the Research Program for the SUS and Fundação de Amparo a Pesquisa do Estado do Rio Grande do Sul (PPSUS/ FAPERGS-2013-2014): Process: 1217-2551/13-0; Conselho Nacional de Desenvolvimento Científico e Tecnológico (CNPq) - Universal call (2013-2016): Process Number: 482554/2013-4; Research Productivity - PQ-2014. Process Number: 307350/2014-2.

2 M.Sc. in Nursing. Universidade Federal de Santa Maria (UFSM). Santa Maria, Rio Grande do Sul, Brazil. E-mail: grazielapiovesan@ hotmail.com

${ }^{3}$ Ph.D. in Nursing. Professor. UFSM. Santa Maria, Rio Grande do Sul, Brazil. E-mail:cris_depaula1@hotmail.com

${ }^{4}$ Ph.D. in Nursing. Professor. UFSM. Santa Maria, Rio Grande do Sul, Brazil. E-mail: lflopes67@yahoo.com.br

${ }^{5}$ Ph.D. in Nursing. Professor. UFSM. Santa Maria, Rio Grande do Sul, Brazil. E-mail: stelamaris_padoin@hotmail.com

${ }^{6}$ Ph.D. student in Nursing. UFSM. Santa Maria, Rio Grande do Sul, Brazil. E-mail: raquel_e_k@hotmail.com

7 Ph.D. student in Nursing. Grantee, Coordenação de Aperfeiçoamento de Pessoal de Nível Superior (CAPES). Universidade Federal do Rio Grande do Sul. Porto Alegre, Rio Grande do Sul, Brazil. E-mail: clabohrer@gmail.com
\end{abstract}

\begin{abstract}
Objective: evaluate, based on the professionals' experience, the primary health care quality in home cities of children and adolescents with HIV, treated at a specialized service.

Method: cross-sectional study involving 527 professionals in 25 interior cities in Rio Grande do Sul, Brazil, in the first semester of 2014. The Primary Care Assessment Tool was applied. Pearson's chi-square Test, the Mann Whitney Test and the Poisson Regression were used.

Results: the Estratégia Saúde da Família and the primary health care service presented a high score related to the essential attributes: longitudinality (7.17 and 6.74), coordination-integration of care (6.87 and 7.03) and coordination-information systems (8.24 and 8.19); and a low score for the attribute access (3.96 and 3.8). The variables: female gender $(0.009)$, education as general practitioner $(<0.001)$, statutory staff (0.029), coordinator position (0.087) and not having another job (0.027) were also associated with the high score.
\end{abstract}

Conclusion: the coverage of the Estratégia Saúde da Família needs to be expanded and structural and organizational shortages in the access need to be overcome.

DESCRIPTORS: HIV. Primary health care. Child health. Adolescent health. Health services evaluation.

\section{QUALIDADE DA ATENÇÃO PRIMÁRIA NA PERSPECTIVA DE PROFISSIONAIS: SAÚDE DE CRIANÇAS E ADOLESCENTES COM HIV}

\section{RESUMO}

Objetivo: avaliar, na experiência dos profissionais, a qualidade da atenção primária à saúde de municípios de procedência de crianças e adolescentes com HIV, acompanhados em serviço especializado.

Método: estudo transversal, com instrumento de avaliação da atenção primária, aplicado a 527 profissionais em 25 municípios do interior do Estado do Rio Grande do Sul, Brasil. Foi utilizado o teste do qui-quadrado de Pearson, de Mann Whitney e regressão de Poisson.

Resultados: Estratégia Saúde da Família e unidade básica de saúde apresentaram alto escore dos atributos: longitudinalidade (7,17 e 6,74), coordenação integração de cuidados $(6,87$ e 7,03$)$, coordenação sistemas de informação $(8,24$ e 8,19$)$ e baixo escore no atributo acesso $(3,96$ e 3,8). As variáveis: sexo feminino $(0,009)$, formação clínico-geral $(<0,001)$, vínculo estatutário $(0,029)$, cargo de coordenador $(0,087)$ e não possuir outro emprego $(0,027)$ estiveram associadas ao alto escore.

Conclusão: ampliar a cobertura de Estratégia Saúde da Família e superar carências estruturais e organizacionais de acesso.

DESCRITORES: HIV. Atenção primária à saúde. Saúde da criança. Saúde do adolescente. Avaliação de serviços de saúde. 


\title{
CALIDAD DE LA ATENCIÓN PRIMARIA EN LA PERSPECTIVA DE PROFESIONALES: SALUD DE NIÑOS Y ADOLESCENTES CON SIDA
}

\begin{abstract}
RESUMEN
Objetivo: evaluar, en la experiencia de los profesionales, la calidad de la atención primaria de salud de municipios de procedencia de niños y adolescencia con VIH, acompañados en servicio especializado.

Método: estudio transversal con 527 profesionales de los 25 municipios del interior de la Provincia del Rio Grande del Sur, Brasil, en el primer semestre del 2014. Se utilizó el Instrumento de Evaluación de la Atención Primaria. Fueron utilizados el test ji-cuadrado de Pearson, Test de Mann Whitney y la regresión de Poisson.

Resultados: Estratégia Saúde da Família y unidad básica de salud presentaron alta puntación cuanto a los atributos esenciales: longitudinalidad $(7,17$ y 6,74), coordinación integración de cuidados $(6,87$ y 7,03), coordinación sistemas de información $(8,24$ y 8,19); y baja puntuación para el atributo acceso $(3,96$ y 3,8). Las variables: sexo femenino $(0,009)$, formación clínico general $(<0,001)$, vínculo estatutario $(0,029)$, cargo de coordinador $(0,087)$ y no poseer otro empleo $(0,027)$ también se mostraron asociadas a la alta puntuación.
\end{abstract}

Conclusión: ts fundamental ampliar la cobertura de Estratégia Saúde da Família, además de superar las carencias estructurales y organizacionales indicadas por el acceso.

DESCRIPTORES: VIH. Atención primaria de salud. Salud del niño. Salud del adolescente. Evaluación de servicios de salud.

\section{INTRODUCTION}

In the 1990's, investments in antiretroviral treatment for HIV influenced the morbidity and mortality rates of children and adolescents, implying the need for health monitoring due to the chronic condition. ${ }^{1}$ The health services in Brazil, however, are structured for the clinical management of acute conditions. ${ }^{2}$ That results in the search to solve health problems at the specialized services. To guarantee that this population receives a better quality of care, however, the care needs to be integrated between the specialized care services and the primary health care (PHC) services. ${ }^{3}$

PHC is defined as an inseparable set of structural elements of the health service system. These elements are key attributes (access, longitudinality, comprehensiveness and coordination), which measure the potential capacity and performance. ${ }^{4-5}$ The first contact access consists of the accessibility and use of the health service as a source of care for every new health problem or episode. ${ }^{6}$ The longitudinality presupposes the existence of a continuous source of care and its use over time. Comprehensiveness implies the availability and provision of care through appropriate prevention, promotion, cure and rehabilitation actions in this care context, so that the user obtains the services needed. ${ }^{7}$ Coordination refers to the integration of global user care among the different services. ${ }^{5}$

In Brazil, PHC is a proposal that consists of the Family Health Strategy (Estratégia Saúde da Família) services and the Primary Health Care services (PHC). The FHS is indicated by the Ministry of Health to reorient the Unified Health System (SUS) and expand this proposal. The Strategy has demonstrated a positive impact on the Brazilian health system, as evidenced by indicators, such as lower child mortality and greater quality of prenatal and child care. ${ }^{5}$

In that sense, it serves as the preferred point of contact between the users, families and community and the SUS. At these services, health promotion, health maintenance, early detection, disease screening, treatment and rehabilitation care is offered. ${ }^{2,4}$

Children and adolescents with HIV present clinical and developmental health monitoring demands. These clinical demands, related to the chronic condition, are mainly solved at specialized services, implying not only the longitudinality, but also the coordination of care. The childcare segment, however, which can be offered at the FHS and PHC, represents a gap in the Brazilian care practice. This limitation in the care network appoints the need to structure the actions each service is responsible for, as well as intersectoral communication. Therefore, the integration among the services is fundamental, which can be established through a user flow in the health system. ${ }^{3}$

One study recommends that PHC promote care, considering the individual, family and social context, which can support the treatment compliance and the solution of non-specific complaints or comorbidities. In addition, PHC should maintain the active search for users and a shared information system among the services, ${ }^{3}$ so that the professionals acknowledge this task with a view to the qualification of primary health care for the population.

Hence, this study was justified by the need to assess the PHC performance and structure as the preferred access into the SUS. We believe that guaranteeing the access to health care at services of low technological density can qualify the health maintenance actions.

Considering that the presence and range of the key attributes qualify health care, the objective was 
to assess, based on the professionals' experience, the quality of PHC in home cities of children and adolescents with HIV, monitored at a specialized service.

\section{METHOD}

A cross-sectional study was developed, involving health professionals from PHC and FHS in 25 cities in the interior of the State of Rio Grande do Sul, Brazil. These were listed as the home cities of children and adolescents with HIV infection under continuing monitoring at a specialized service in the University Hospital of Santa Maria. The service is located in the central area of the State of Rio Grande do Sul, in a medium-sized city of 261 thousand inhabitants. Eighty children and adolescents were registered for outpatient monitoring.

The inclusion criteria were: physician, nurse and dental surgeon working in PHC. Professionals on holiday or leave during the data collection period were excluded. In total, 596 professionals were identified, 42 of whom did not comply with the inclusion criteria $(7.0 \%)$. In the eligible population of 554 professionals, 12 refused and 15 could not be contacted, totaling 27 losses (4.9\%). Thus, the study population consisted of 527 health professionals.

Research auxiliaries who had received background training from the research coordinator collected the data between March and August 2014. Nine people collected the data, being four Master's students and five scientific initiation grantees from the undergraduate nursing program. The supervision of the field phase took place during weekly meetings of the research group, aiming to discuss the easy and difficult aspects.

The municipal health departments were contacted to authorize the research and grant access to the UBS and FHS addresses. The PHC coordinator in each city arranged for the scheduling of the interviews. The research auxiliaries visited the cities, using resources from projects funded by research agencies.

To characterize the professionals, a tool was used with sociodemographic variables: age (in years; dichotomous); sex (female, male); marital situation (married, single, other); academic education variables: education, time since graduation (in years; dichotomous); post-graduate degree (residency, specialization and Master's), conclusion of post-graduate degree (in years; dichotomous), complementary education (yes, no) and professional situation variables: affiliation (contracted, statutory, outsourced), length of experience (in years; dichotomous), function at the service (yes, no), type of function (technical responsible, coordinator, responsible for community health agents), other job (yes, no), totaling 13 items, listed based on the review of background research on the theme.

In this study, the assessment of the quality of health care (dependent variable) was considered as the presence and range of the key attributes of PHC. ${ }^{4}$ To measure these, the Primary Care Assessment Tool (PCATool-Brazil), Professional version, was applied, which consists of key (access, longitudinality, comprehensiveness and coordination) and derived (family orientation and community orientation) attributes. ${ }^{8}$ Although this tool does not specifically target the population of children and adolescents living with HIV, during its application, the professionals were instructed to answer it focused on the health of this population.

In this study, is presented the analysis of the key attributes. Answers, on a Likert scale, were: "certainly yes" (score=4), "probably yes" (score=3), "probably no" (score=2), "certainly no" (score=1) and "I don't know/I don't remember" (score=9). Answers marked as "I don't know / I don't remember" were considered as "probably not". ${ }^{8}$

To include the data, the software Epi-info ${ }^{\circledR}$, version 7.0 was used, with independent double-data entry to guarantee the exactness of the data. After checking for errors and inconsistencies, the data were analyzed in the software Statistical Analysis System (SAS) version 9.3.

To analyze the PCATool-Brazil, first, the scores of the key attributes of PHC were calculated. The scores, which originally ranged between 1 and 4 , were transformed into a continuing scale from 0 to 10 , according to the formula: score from 0 to 10 of attribute $X=$ (score from 1 to 4 of attribute $X-1$ ) $x$ 10/(4-1). For the assessment, the scores were dichotomized, with scores $>6.6$ corresponding to high score and $<6.6$ to low score, according to the tool manual. The high score was defined as the satisfactory range of each attribute and low score as the unsatisfactory range. ${ }^{8}$

For the reliability analysis of the PCAToolBrazil, Cronbach's alpha was used (considering coefficients $>0.7$ as indicators of consistency). The categorical variables were presented as absolute and relative frequencies and the continuing variables as means and standard deviations in case of symmetrical distribution and medians and interquartile intervals in case of asymmetrical distribution. For all statistical analyses, significance was set at 5\%.

To compare the proportions of the dichotomized scores of the PHC attributes between the 
participants' sociodemographic, educational and professional profile, Pearson's chi-square test was used. To compare the scores of the key attributes of the PHC according to the type of service (FHS or UBS) and to compare the items of the first contact access attribute, dichotomized into high and low score, the Mann-Whitney test was used.

Poisson's regression with robust variation was applied to verify the variables associated with the high score, estimating the prevalence ratios (PR) and their respective confidence intervals (95\% CI). In the gross and adjusted analyses, the independent variables associated with the high score, with $\mathrm{p}<0.25$, were included.

Approval for the project was obtained from the Ethic Research Committee at Universidade Federal de Santa Maria (CAAE:12223312.3.0000.5346), in compliance with the recommendations of Resolution N. 466/12. All professionals who participated in the research signed the Free and Informed Consent Form and the ethical premises were respected.

\section{RESULTS}

In the health professionals' assessment of the PHC quality, the essential PHC score estimated using the PCATool-Brazil resulted in 6.64 (standard deviation 1.02), representing a satisfactory score for PHC orientation. The first contact access, on the other hand, scored 3.89 (standard deviation 1.49), considered below the ideal quality of PHC.

In the association between the essential high/ low score and the variables of the professionals' sociodemographic and educational profile, the statistically significant items for a high score were: female sex; professional education as general practitioner; statutory staff; function as service coordinator. The statistically significant items for a low score were: not having another job (Table 1).

Table 1 - Sociodemographic educational and job profile of health professionals according to the high and low essential score for primary health care, from 25 cities in Rio Grande do Sul, Brazil, 2014. (n=527)

\begin{tabular}{|c|c|c|c|c|}
\hline Variable & Category & $\begin{array}{c}\text { High essential } \\
\text { score }(\geq 6.6) \\
n(\%) \\
\end{array}$ & $\begin{array}{c}\text { Low essential } \\
\text { score }(<6.6) \\
n(\%)\end{array}$ & p-value $\dagger$ \\
\hline \multirow{2}{*}{ Age } & $\geq 30$ years & $53(10.06)$ & $54(10.25)$ & \multirow{2}{*}{0.387} \\
\hline & $<30$ years & $228(43.26)$ & $192(36.43)$ & \\
\hline \multirow{3}{*}{ Sex } & Female & $195(37.00)$ & $144(27.32)$ & \multirow{2}{*}{0.009} \\
\hline & Male & $86(16.32)$ & $102(19.35)$ & \\
\hline & Married & $177(33.65)$ & $165(31.37)$ & \multirow{3}{*}{0.125} \\
\hline \multirow[t]{2}{*}{ Marital situation* } & Single & $81(15.40)$ & $54(10.27)$ & \\
\hline & Other & $22(4.18)$ & $27(5.13)$ & \\
\hline \multirow{5}{*}{ Education } & General Practitioner & $102(19.35)$ & $72(13.66)$ & \multirow{5}{*}{$<0.001$} \\
\hline & Gynecologist & $15(2.85)$ & $23(4.36)$ & \\
\hline & Pediatrician & $21(3.98)$ & $12(2.28)$ & \\
\hline & Nurse & $100(18.98)$ & $67(12.71)$ & \\
\hline & Dental surgeon & $43(8.16)$ & $72(13.66)$ & \\
\hline \multirow{3}{*}{ Time since graduation* } & $\leq 15$ years & $155(29.47)$ & $119(22.62)$ & \multirow{2}{*}{0.109} \\
\hline & $>15$ years & $125(23.76)$ & $127(24.14)$ & \\
\hline & None & $67(12.71)$ & $71(13.47)$ & \multirow{4}{*}{0.275} \\
\hline \multirow{3}{*}{ Post-graduation $\ddagger$} & Residency & $52(9.87)$ & $52(9.87)$ & \\
\hline & Specialization & $153(29.03)$ & $113(21.44)$ & \\
\hline & Master's & $09(1.71)$ & $10(1.90)$ & \\
\hline \multirow{2}{*}{$\begin{array}{l}\text { Conclusion of post-gradua- } \\
\text { tion }(n=390)\end{array}$} & $\leq 6$ years & $121(31.03)$ & $84(21.54)$ & \multirow{2}{*}{0.103} \\
\hline & $>6$ years & $94(24.10)$ & $91(23.33)$ & \\
\hline \multirow{2}{*}{ Complementary education } & Yes & $238(45.16)$ & $207(39.28)$ & \multirow{3}{*}{0.861} \\
\hline & No & $43(8.16)$ & $39(7.40)$ & \\
\hline \multirow{3}{*}{ Affiliation with the service* } & Contracted & $79(15.02)$ & $57(10.84)$ & \\
\hline & Statutory & $198(37.64)$ & $178(33.84)$ & \multirow[t]{2}{*}{0.029} \\
\hline & Outsourced & $03(0.57)$ & $11(2.09)$ & \\
\hline
\end{tabular}




\begin{tabular}{|c|c|c|c|c|}
\hline Variable & Category & $\begin{array}{c}\text { High essential } \\
\text { score }(\geq 6.6) \\
n(\%) \\
\end{array}$ & $\begin{array}{c}\text { Low essential } \\
\text { score }(<6.6) \\
n(\%) \\
\end{array}$ & p-value \\
\hline \multirow{2}{*}{$\begin{array}{l}\text { Length of experience at the } \\
\text { service* }\end{array}$} & $\leq 3$ years & $147(27.95)$ & $120(22.81)$ & \multirow{2}{*}{0.445} \\
\hline & $>3$ years & $134(25.48)$ & $125(23.76)$ & \\
\hline \multirow{2}{*}{ Function at the service* } & Yes & $55(10.46)$ & $35(6.65)$ & \multirow{2}{*}{0.108} \\
\hline & No & $226(42.97)$ & $210(39.92)$ & \\
\hline \multirow{3}{*}{ What function $(\mathrm{n}=87) \S$} & Technical responsible & $13(14.94)$ & $14(16.09)$ & \multirow{3}{*}{0.087} \\
\hline & Coordinator & $40(45.98)$ & $17(19.54)$ & \\
\hline & $\mathrm{CHA}$ responsible & $01(1.15)$ & $02(22.30)$ & \\
\hline \multirow{2}{*}{ Having another job } & Yes & $134(25.43)$ & $141(26.76)$ & \multirow{2}{*}{0.027} \\
\hline & No & $147(27.89)$ & 105 (19.92) & \\
\hline
\end{tabular}

* one participant did not answer the question; † Pearson's chi-square test; $\ddagger$ multiple-choice question/more than one answer; $\S$ three participants did not answer the question.

When comparing the key attributes of PHC between the types of services assessed, a significant difference was observed in favor of the FHS: longitudinality (7.17); comprehensiveness of available services (7.17) and comprehensiveness of services provided (7.66). Among the worst assessed attributes at the UBS and FHS, the first contact access stands out (Table 2).

Table 2 - Comparison of scores for key attributes of PHC concerning health care for children and adolescents with HIV in the experience of health professionals from 25 cities in Rio Grande do Sul, Brazil, 2014. $(n=527)$

\begin{tabular}{|c|c|c|c|c|c|c|c|}
\hline \multirow[t]{2}{*}{ Key attributes } & \multicolumn{3}{|c|}{$\begin{array}{l}\text { Primary Health Care Service } \\
\qquad(\mathrm{n}=270)\end{array}$} & \multicolumn{3}{|c|}{$\begin{array}{l}\text { Family Health Strategy } \\
\qquad(n=257)\end{array}$} & \multirow[t]{2}{*}{ p-value $\nmid$} \\
\hline & Mean (SD*) & Median & Min-Max & Mean (SD*) & Median & Min-Max & \\
\hline First contact access & $3.96(1.78)$ & 3,33 & $0,74-9,63$ & $3,80(1,09)$ & 3,70 & $1,85-9,26$ & 0,655 \\
\hline Longitudinality & $6.74(1.34)$ & 3,67 & $3,08-10$ & $7,17(1,24)$ & 7,18 & $4,10-10$ & $<0,001$ \\
\hline $\begin{array}{l}\text { Coordination care } \\
\text { integration }\end{array}$ & $7.03(1.51)$ & 7,22 & $1,67-10$ & $6,87(1,50)$ & 6,67 & $2,22-10$ & 0,164 \\
\hline $\begin{array}{l}\text { Coordination infor- } \\
\text { mation systems }\end{array}$ & $8.19(1.87)$ & 8,89 & $0-10$ & $8,24(1,50)$ & 8,89 & $3,33-10$ & 0,502 \\
\hline $\begin{array}{l}\text { Comprehensiveness } \\
\text { available services }\end{array}$ & 6.49 (1.77) & 6,67 & $1,54-9,74$ & $7,17(1,52)$ & 7,18 & $2,31-10$ & $<0,001$ \\
\hline $\begin{array}{l}\text { Comprehensiveness } \\
\text { services provided }\end{array}$ & $6.37(2.77)$ & 6,67 & $0-10$ & $7,66(1,96)$ & 8,00 & $1,33-10$ & $<0,001$ \\
\hline $\begin{array}{l}\text { Essential primary } \\
\text { health care score }\end{array}$ & $6.47(1.10)$ & 6,53 & $2,77-9,15$ & $6,82(0,88)$ & 6,86 & $4,6-9$ & $<0,001$ \\
\hline
\end{tabular}

* SD: standard deviation;† Mann Whitney test

In table 3, the items of the access attribute are displayed, dichotomized into high and low PHC score, concerning the health care for children and adolescents with HIV in the experience of health professionals per type of service (UBS and FHS). 
Table 3 - Comparison of items for the first contact access attribute, dichotomized into high and low score, according to the type of service, according to the assessment of health professionals from 25 cities in Rio Grande do Sul, Brazil, 2014. ( $\mathrm{n}=524)$

\begin{tabular}{|c|c|c|c|c|c|c|}
\hline \multirow[b]{2}{*}{ Variables } & \multicolumn{2}{|c|}{$\begin{array}{l}\text { Primary Health Care Service } \\
\qquad(n=270)\end{array}$} & \multirow[b]{2}{*}{ p-value ${ }^{*}$} & \multicolumn{2}{|c|}{$\begin{array}{l}\text { Family Health Strategy } \\
(\mathrm{n}=254)\end{array}$} & \multirow[b]{2}{*}{ p-value* } \\
\hline & $\begin{array}{l}\text { High Score } \\
(\geq 6.6) \\
\text { n }(\%)\end{array}$ & $\begin{array}{c}\text { Low Score } \\
(<6.6) \\
\text { n }(\%)\end{array}$ & & $\begin{array}{l}\text { High Score } \\
\quad(\geq 6.6) \\
n(\%)\end{array}$ & $\begin{array}{c}\text { Low Score } \\
(<6.6) \\
\text { n }(\%)\end{array}$ & \\
\hline $\begin{array}{l}\text { Open Saturdays or } \\
\text { Sundays }(n=268)\end{array}$ & $16(5.97)$ & $252(94.03)$ & $<.0001$ & 5 (1.97) & 249 (98.03) & $<.0001$ \\
\hline $\begin{array}{l}\text { Open at least some } \\
\text { days until } 8 \text { p.m. } \\
(n=268)\end{array}$ & 45 (16.79) & $223(83.21)$ & $<.0001$ & $9(3.54)$ & 245 (96.46) & $<.0001$ \\
\hline $\begin{array}{l}\text { When open, someone } \\
\text { from your service } \\
\text { would attend to you } \\
\text { on the same day } \\
(n=268)\end{array}$ & $173(64.55)$ & $95(35.45)$ & $<.0001$ & $190(74.80)$ & $64(25.20)$ & $<.0001$ \\
\hline $\begin{array}{l}\text { When open, rapid } \\
\text { counseling by phone } \\
\text { when considered } \\
\text { necessary. }(n=262)\end{array}$ & 85 (32.32) & $178(67.68)$ & $<.0001$ & 135 (53.36) & $118(46.64)$ & 0.285 \\
\hline $\begin{array}{l}\text { When close, there is } \\
\text { a contact telephone } \\
\text { number }(n=256)\end{array}$ & 51 (19.47) & $211(80.53)$ & $<.0001$ & $24(9.68)$ & $224(90.32)$ & $<.0001$ \\
\hline $\begin{array}{l}\text { When closed on } \\
\text { Saturdays and } \\
\text { Sundays, attendance } \\
\text { on that day by } \\
\text { someone from the } \\
\text { service }(n=264)\end{array}$ & $28(10.57)$ & 237 (89.43) & $<.0001$ & $7(2.77)$ & $246(97.23)$ & $<.0001$ \\
\hline $\begin{array}{l}\text { When closed at night, } \\
\text { attendance the same } \\
\text { night by someone } \\
\text { from the service } \\
(n=266)\end{array}$ & 27 (10.11) & $240(89.89)$ & $<.0001$ & $10(3.95)$ & $243(96.05)$ & $<.0001$ \\
\hline $\begin{array}{l}\text { Easy to schedule } \\
\text { a return health } \\
\text { appointment }(n=268)\end{array}$ & $132(49.25)$ & 136 (50.75) & 0.807 & 168 (66.14) & $86(33.86)$ & $<.0001$ \\
\hline $\begin{array}{l}\text { Waiting more than } \\
30 \text { minutes to see the } \\
\text { physician or nurse } \\
(n=268)\end{array}$ & $68(25.37)$ & $200(74.63)$ & $<.0001$ & $42(16.54)$ & $212(83.46)$ & $<.0001$ \\
\hline $\begin{array}{l}\text { First contact access } \\
\text { attribute }\end{array}$ & $24(8.89)$ & 246 (91.11) & $<.0001$ & $14(5.51)$ & 240 (94.49) & $<.0001$ \\
\hline
\end{tabular}

*Pearson's chi-square test.

In table 4, the gross and adjusted Poisson regression demonstrates the association between the independent variables and the high PHC score concerning the health care for children and adolescents with HIV in the experience of the health professionals. 
Table 4 - Gross and adjusted regression for essential primary health care score according to health professionals from 25 cities in Rio Grande do Sul, Brazil, 2014. (n=527)

\begin{tabular}{|c|c|c|c|c|c|c|c|c|}
\hline \multirow{3}{*}{ Variables } & \multicolumn{8}{|c|}{ High Score } \\
\hline & \multirow[t]{2}{*}{ PRg* } & \multicolumn{2}{|c|}{$95 \% \mathrm{CI} \dagger$} & \multirow[t]{2}{*}{ p } & \multirow[t]{2}{*}{ PRał } & \multicolumn{2}{|c|}{$95 \% \mathrm{CI} \dagger$} & \multirow[t]{2}{*}{$\mathrm{p}$} \\
\hline & & Minimum & Maximum & & & Minimum & Maximum & \\
\hline \multicolumn{9}{|l|}{ Post-graduation } \\
\hline Specialization & 0.906 & 0.785 & 1.046 & 0.180 & 0.914 & 0.791 & 1.055 & 0.217 \\
\hline None & 0.926 & 0.799 & 1.073 & 0.308 & 0.930 & 0.803 & 1.077 & 0.333 \\
\hline Residency & 0.963 & 0.083 & 1.121 & 0.629 & 0.952 & 0.818 & 1.108 & 0.522 \\
\hline Master's & ref§ & & & & ref§ & & & \\
\hline \multicolumn{9}{|c|}{ Having another job } \\
\hline Yes & 1.060 & 1.018 & 1.103 & 0.004 & 1.049 & 1.006 & 1.094 & 0.025 \\
\hline No & ref§ & & & & ref & & & \\
\hline
\end{tabular}

*PRg= gross Poisson regression; $† C I$ 95\% = 95\% confidence interval; $\ddagger \mathrm{PRa}=$ Poisson regression adjusted for: post-graduation and having another job; §ref =reference value.

\section{DISCUSSION}

The results appointed that, according to the physicians, nurses and dental surgeons, considering the overall assessment of the key attributes, the PHC services were satisfactory (6.64) for the quality of care provided in the home cities of children and adolescents with HIV. In other studies involving professionals, the assessment of the essential score also revealed good results, in line with PHC. ${ }^{9-11}$

The sociodemographic characteristics evidenced higher frequencies of female professionals, in line with the results found in other studies. ${ }^{9,11}$ That could be attributed to the performance of the care professions, which are attributed to the female universe. $^{12}$

Organizations' encouragement for women to develop their potentials and skills can influence the satisfaction at work. ${ }^{13}$ In addition, the valuation and professional acknowledgement ${ }^{12}$ may have contributed to this finding.

The professionals' education as general practitioners stood out. This finding differs from other studies though, which appointed that health professionals specialized in PHC better assessed this area. ${ }^{9,11}$ Specialization permits the construction of a systematic assessment of the care provided..$^{10}$ This can favor critical thinking in the assessment of the professionals' own actions at the health services.

What the affiliation with the service is concerned, being a statutory staff member was associated with a high essential score. This result converged with the study developed in the microregion of Alfenas-MG (Brazil) where, being a statutory staff member, the professional's length of experience at the service was longer. ${ }^{14}$ This may have contributed to the professionals' satisfactory assessment in this study. Nevertheless, the variables having another job and working as a coordinator have not been investigated in other studies.

The FHS presented significantly higher scores than the UBS attributes for: "longitudinality", "comprehensiveness - available services" and "comprehensiveness - services provided". These results have also been identified in other studies. ${ }^{9,11}$

The FHS represents the service indicated for longitudinal and problem-solving monitoring of most child health problems. In addition, being located close to the community, it favors communication and bonding with the professionals. This permits the better acknowledgement of this population's health situation. In addition, the great supply of continuing education and specialists in PHC enables the FHS to identify and comprehensively manage the health problems that are common in the population, with better performing health professionals. ${ }^{11}$

To deliver health care to children and adolescents with HIV, a regular source of care is needed, which excels by health promotion and disease prevention actions, characteristics of the FHS' activities. In Brazil, longitudinality has been considered the core and exclusive trait of PHC. ${ }^{4}$ This attribute is related to good communication, which tends to favor the monitoring of users, the continuity and the effectiveness of care. ${ }^{15}$ Comprehensiveness, in turn, implies the supply of curative and preventive 
services, favoring the quality of care for children and adolescents. ${ }^{3,16}$

In this study, the components: "coordinationcare integration" and "coordination-information systems" revealed high scores in both services. This result is in line with other studies that used the PCATool-Brazil, professional version..$^{9,11}$ One element that contributed to this attributed was the computer system for the results of laboratory tests, available online in the patient history or when appointments are scheduled. ${ }^{11}$

On the opposite, the access attribute obtained a low score at the UBS as well as the FHS. The analysis of other studies that used the PCATool revealed converging results in the professionals' experience. ${ }^{9-11}$ Among these, a study developed in Chapecó-SC (Brazil) appointed weak points in the first contact access (score 3.6), indicating the need for caution when considering only the professionals' experience in the assessment. ${ }^{10}$

Studies developed with caregivers of children (score 4.72) presented similarity in the assessment of this attribute in $\mathrm{PHC}^{17}$ and also in adults (score 3.8).$^{18}$ These results revealed that, independently of the social actor (professional, adult or caregiver), the first contact access to PHC has been assessed unsatisfactorily.

A study developed in João Pessoa-PB (Brazil) supporting the findings in the assessment of this attribute and related the barriers that negatively affected the access to the compromised bonding, dissatisfaction and discredit of the health service, mainly due to the fact that the chronic condition demanded prolonged and complex treatment concerning the therapeutics and determinants that triggered the child health problems. ${ }^{16}$

Besides the low score for the attribute firstcontact access, at the UBS as well as FHS, when comparing its component items, a dichotomy between a high and low score was found according to the type of service (UBS or FHS). The general score for the access attribute was associated with the low score at both services. This indicated that in this population's experience, these elements were considered unavailable or difficult to obtain at their PHC services, making the access to the health service more difficult for the children and adolescents with HIV when they needed or considered this access to be convenient.

Sometimes, the restricted supply of actions to a certain public impairs the access. Some services restrict the action at the reception desk by supplying access tickets to the medical appointments. These tickets are obtained in queues organized on a firstcome first-served basis, on specific days and for a given population group. In addition, the lack of professionals and services turns $\mathrm{PHC}$ into a narrow and unwelcoming entry door. ${ }^{19}$ On the other hand, studies have reported that forwarding by the community health agents is a strategy that favored the access to appointments at the services. ${ }^{20-21}$

Home care is an alternative care modality for the users' access to the service, guaranteeing the right to care for users who are limited or cannot come to the service. ${ }^{22}$ Another strategy is telephone contact, permitting appointment scheduling and access to care in remote areas. ${ }^{23}$ Long waiting times, however, before and during the consultation with the health professional, negatively influences the users' access to and satisfaction with the service. ${ }^{24}$

The presence of the FHS can favor the access, considering that the expansion of this strategy is essential for the efficacy, equity and rationality of health care, through clinical care and health prevention/ promotion. ${ }^{25}$ Therefore, access barriers need to be overcome which often make the FHS' role as the broad entry door to the SUS unfeasible, despite the wide coverage of this PHC model. Thus, the community within the territory can recognize itself to be affiliated with a certain professional team. ${ }^{26}$

The access to the health services should be guaranteed for the perspective of comprehensive care to whoever seeks the health system. Nevertheless, the fragmentation of care and the lack of communication among the services are observed for the population with HIV ${ }^{27}$ In the case of children and adolescents, a study has appointed that PHC was used for consultations and routine prescriptions, and the specialized team for specific HIV care. Hence, investments are needed for comprehensive care in PHC, with a view to responding to the specific demands of the serologic conditions and of the growth and development phase. ${ }^{28}$

Based on the obtained results, we hope that PHC can promote the health of children and adolescents with HIV, in view of the family and social context. In that sense, PHC should expand the detection of new cases of infection by HIV, transferring the diagnosed patients to the specialized service for specific clinical monitoring, maintaining the monitoring in PHC. This can take place through childcare and care for the modifications of 
puberty, non-specific complaints or comorbidities; compliance with the immunization calendar; family support for treatment compliance; active service and maintenance of a shared information system among the services. These actions can be put in practice in view of the potential the professionals at these services expressed through the high score for the attributes: longitudinality, coordination-care integration and coordination-information systems.

As a limitation in this study, we appoint that the tool does not specifically target the HIV population, making the assessment of peculiar aspects impossible. In addition, the users' possible hiding of the HIV seropositive diagnosis should be highlighted, which sometimes makes it difficulty to identify and assess the care for the demands the PHC professionals could solve.

\section{CONCLUSION}

In the professionals' experience, the assessment of the PHC quality is inferior to the desired level concerning the attribute first contact access, which evidences the need for multiprofessional activity and care decentralization strategies in PHC as well as in specialized services.

What the planning is concerned, we emphasized that attendance on the same day and ease to schedule an appointment were items the professionals assessed positively; nevertheless, the access difficulties to the health services often make the continuity of care impossible, as they distance the users from the services. That can make bonding with the professionals impossible, negatively affecting the relationship of trust that is fundamental to accomplish the health interventions.

Furthermore, the acknowledgement of the weaknesses in the attributes assessed appoints the need to invest in expanded opening hours for PHC and in the professionals' preparation to offer organized and problem solving care to this population.

\section{REFERENCES}

1. Ministério da Saúde (BR), Secretaria de Vigilância Sanitária, Departamento de DST, AIDS e Hepatites Virais. Boletim Epidemiológico AIDS/DST. Brasília (DF): Ministério da Saúde; 2014.

2. Barbiani R, Junges JR, Dalla Nora $C R$, Asquidamini F. A produção científica sobre acesso no âmbito do Sistema Único de Saúde do Brasil: avanços, limites e desafios. Saúde Soc [Internet]. 2014 Jul-
Sept [cited 2016 Jul 12]; 23(3):855-68. Available from: http://www.scielo.br/scielo.php?script=sci arttext\&pid=S0104-12902014000300855

3. Silva CB, Paula CC, Lopes LFD, Harzheim E, Magnago TSBS, Schimith MD. Atenção à saúde de criança e adolescente com HIV: comparação entre serviços. Rev Bras Enferm. [Internet]. 2016 Jun [cited 2016 Jul 12]; 69(3):522-31. Available from: http://www.scielo.br/scielo.php?script=sci_ arttext\&pid $=$ S0034-71672016000300522\&lng=pt. http:/ /dx.doi.org/10.1590/0034-7167.2016690315i

4. Starfield B. Atenção primária: equilíbrio entre necessidades de saúde, serviços e tecnologia. Organização das Nações Unidas para a Educação, a Ciência e a Cultura. Brasília (DF): Ministério da Saúde; 2002

5. Oliveira MAC, Pereira IC. Atributos essenciais da Atenção Primária e a Estratégia Saúde da Família. Rev Bras Enferm [Internet]. 2013 Sept [cited 2016 Jul 12]; 66(spe):158-64. Available from: http:/ / www.scielo.br/scielo.php? script $=$ sci arttext\&pid=S0034-71672013000700020

6. Oliveira BRG, Viera CS, Collet N, Lima RAG. Acesso de primeiro contato na atenção primária em saúde para crianças. Rev RENE [Internet]. 2012 Mar-Apr [cited 2016 Jul 12]; 13(2):332-42. Available from: http://www.revistarene.ufc.br/revista/index.php/ revista/article/view/217/pdf

7. Braz JC, Mello DF, David YGM, Teixeira SA, Prado AS, Furtado MCC. Longitudinalidade e integralidade no cuidado a menores de um ano: avaliação de cuidadores. Medicina (Ribeirão Preto) [Internet]. 2013 [cited 2016 Jul 12]; 46(4):416-23. Available from: http://revista.fmrp.usp.br/2013/vol46n4/AO_a\%20 Longitudinalidade $\% 20 \mathrm{e} \% 20$ integralidade $\% 20$ no $\% 20$ cuidado $\% 20$ a $\% 20$ menores $\% 20 \mathrm{de} \% 20 \mathrm{um} \% 20$ ano.pdf

8. Ministério da Saúde (BR), Secretaria de Atenção em Saúde. Departamento de Atenção Básica. Manual do instrumento de avaliação da atenção primária à saúde: primary care assessment tool pcatool Brasil. Brasília (DF): Ministério da Saúde; 2010.

9. Chomatas E, Vigo A, Marty I, Hauser L, Harzheim E. Avaliação da presença e extensão dos atributos da atenção primária em Curitiba. Rev Bras Med Fam Comunidade [Internet]. 2013 Out-Dez [cited $2016 \mathrm{Jul}$ 12]; 8(29):294-303. Available from: https://www. rbmfc.org.br/rbmfc/article/view/828

10. Vitoria AM, Harzheim E, Takeda SP, Hauser L. Avaliação dos atributos da atenção primária à saúde em Chapecó, Brasil. Rev Bras Med Fam Comunidade [Internet]. 2013 Out-Dez [cited 2016 Jul 12]; 8(29):285- 
93. Available from: https://www.rbmfc.org.br/ rbmfc/article/view/832

11. Castro RCL, Knauth DR, Harzheim E, Hauser L, Duncan BB. Avaliação da qualidade da atenção primária pelos profissionais de saúde: comparação entre os diferentes tipos de serviços. Cad Saúde Pública [Internet]. 2012 Set [cited 2016 Jul 12]; 28(9):1772-84. Available from: http://www.scielo. br/scielo.php?script=sci_arttext\&pid=S0102311X2012000900015

12. Souza LL, Araújo DB, Silva DS, Bêrredo VCM. Representações de gênero na prática de enfermagem na perspectiva de estudantes. Ciênc Cognição [Internet]. 2014 [cited 2016 Jul 12]; 19(2):218-32. Available from: http://www.cienciasecognicao.org/ revista/index.php/cec/article/view/908

13. Mattos AHG. A ocupação feminina no mercado de trabalho: desafios para a gestão contemporânea das organizações. Gestão Contemporânea [Internet]. 2009 Jan-Dez [cited 2016 Jul 12]; 6(6):23-43. Available from: http://seer4.fapa.com.br/index.php/arquivo/ article/view/4

14. Silva SA, Nogueira DA, Paraizo CMS, Fracolli LA. Assessment of primary health care: health professionals' perspective. Rev Esc Enferm USP [Internet]. 2014 Aug [cited 2016 Jul 12]; 48(spe):126-32. Available from: http:/ / www.scielo.br/scielo.php?script=sci_ arttext\&pid=S0080-62342014000700122

15. Mello DF, Furtado MCC, Fonseca LMM, Pina JC. Seguimento da saúde da criança e a longitudinalidade do cuidado. Rev Bras Enferm [Internet]. 2012 Jul-Ago [cited 2016 Jul 12]; 65(4):675-9. Available from: http:/ / www.scielo.br/scielo.php?script=sci_ arttext\&pid=S0034-71672012000400018

16. Nóbrega VM, Damasceno SS, Rodrigues PF, Reichert APS, Collet N. Atenção à criança com doença crônica na estratégia saúde da família. Cogitare Enferm [Internet]. 2013 Jan-Mar [cited 2016 Jul 12]; 18(1):5763. Available from: http:// revistas.ufpr.br/cogitare/ article/view/28517

17. Harzheim E, Pinto LF, Hauser L, Soranz D. Avaliação dos usuários crianças e adultos quanto ao grau de orientação para Atenção Primária à Saúde na cidade do Rio de Janeiro, Brasil. Ciênc Saúde Coletiva [Internet]. 2016 [cited 2016 Jul 12]; 21(5):1399-408. Available from: http://www.scielo.br/scielo. php?pid=S141381232016000501399\&script $=$ sci $_{-}$ abstract\&tlng $=p t$

18. Araujo LUA, Gama ZAS, Nascimento FLA, Oliveira HFV, Azevedo WM, Almeida Junior HJB. Avaliação da qualidade da atenção primária à saúde sob a perspectiva do idoso. Ciênc Saúde Colet [Internet]. 2014 Aug [cited 2016 Jul 12]; 19(8): 3521-32. Available from: http:/ / www.scielo.br/scielo.php?script=sci_ arttext\&pid=S1413-81232014000803521

19. Sousa FOS, Medeiros KR, Gurgel Júnior GD, Albuquerque PC. Do normativo à realidade do Sistema Único de Saúde: revelando barreiras de acesso na rede de cuidados assistenciais. Ciênc. Saúde Coletiva [Internet]. 2014 Apr [cited 2016 Jul 12]; 19(4):1283-93. Available from: http:/ / www.scielo.br/ scielo.php?pid=S141381232014000401283\&script $=$ sci_ abstract\&tlng $=\mathrm{pt}$

20. Lima SAV, Silva MRF, Carvalho EMF, Cesse EAP, Brito ESV, Braga JPR. Elementos que influenciam o acesso à atenção primária na perspectiva dos profissionais e dos usuários de uma rede de serviços de saúde do Recife. Physis Revista de Saúde Coletiva [Internet]. 2015 Apr-Jun [cited 2016 Jul 12]; 25(2):635-56. Available from: http://www.scielo.br/scielo.php?script=sci_ arttext\&pid=S0103-73312015000200635

21. Duarte ED, Silva KL, Tavares TS, Nishimoto CLJ, Silva PM, Sena RR. Cuidado à criança em condição crônica na atenção primária: desafios do modelo de atenção à saúde. Texto Contexto Enferm [Internet]. 2015 Dec [cited 2016 Jul 12]; 24(4):1009-17. Available from: http://www.scielo.br/pdf/tce/v24n4/pt_0104-0707tce-24-04-01009.pdf

22. Marcolin GCA, Montenário JVC, Borges CM, Souza AR, Barbosa ACS. Panorama da atenção domiciliar do sistema único de saúde (SUS): correlatividade com os serviços de atenção primária. Teoria e Sociedade [Internet]. 2014 Jul-Dez [cited 2016 Jul 12]; (22.2):e22. Available from: http://www.fafich.ufmg.br/ revistasociedade/index.php/rts/article/view/196

23. Fausto MCR, Giovanella L, Mendonça MHM, Seidl H, Gagno J. A posição da Estratégia Saúde da Família na rede de atenção à saúde na perspectiva das equipes e usuários participantes do PMAQAB. Saúde Debate [Internet]. 2014 Out [cited 2016 Jul 12]; 38 (spe): 13-33. Available from: http:/ / www.scielo.br/scielo.php? script $=$ sci $_{-}$ arttext\&pid=S0103-11042014000600013

24. Oliveira LPBA, Medeiros LMF, Meirelles BHS, Santos SMA. Satisfaction of the elderly population attended in the family health strategy in Santa Cruz, Rio Grande do Norte, Brazil. Text Context Nursing [Internet]. 2014 Oct-Dec [cited 2016 Jul 12]; 23(4):871-9. Available from: http:/ / www.scielo.br/scielo.php?script=sci arttext\&pid=S0104-07072014000400871

25. Norman AH, Tesser CD. Access to healthcare in the Family Health Strategy: balance between same day 
access and prevention/health promotion. Saúde Soc [Internet]. 2015 [cited 2016 Jul 12]; 24(1):165-79. Available from: http:/ / www.scielo.br/scielo.php?pid=S0104$12902015000100165 \&$ script $=$ sci_abstract

26. Silva SA, Baitelo TC, Fracolli LA. Primary Health Care Evaluation: the view of clients and professionals about the Family Health Strategy. Rev Latino-Am Enfermagem [Internet]. 2015 SeptOct [cited 2016 Jul 12]; 23(5):980-7. Available from: http://www.scielo.br/scielo.php?script=sci_ arttext\&pid=S0104-11692015000500979

27. Lopes LM, Magnabosco GT, Andrade RLP, Ponce MAZ, Wysocki AD, Ravanholi GM, et al. Coordenação da assistência prestada às pessoas que vivem com HIV/AIDS em um município do Estado de São Paulo, Brasil. Cad Saúde Pública [Internet]. 2014 Nov [cited 2016 Jul 12]; 30(11):2283-97. Available from: http:/ / www.scielosp.org/ scielo.php? script $=$ sci $_{-}$ arttext\&pid=S0102-311X2014001202283

28. Alvarenga WA, Galvão MTG, Nascimento LC, Beretta MIR Dupas G. Weakened social network: the experience of caregivers of the HIV-exposed infant. Texto Contexto Enferm [Internet]. 2015 Jul-Set [cited 2016 Jul 12]; 24(3):775-83. Available from: http:/ / www.scielo.br/scielo.php?script=sci_ arttext\&pid=S0104-07072015000300775 